\title{
TROPHY SMOOTHIES FOR TEEN BREAKFAST: A BUSINESS MODEL CANVAS APPROACH
}

\author{
Novsa Fakhira*)1, Andina Oktariani*), and Nimmi Zulbainarni*) \\ *) School of Business, IPB University \\ Jl. Pajajaran, Bogor 16151
}

\begin{abstract}
Most teenagers in Indonesia ignore breakfast as an important activity and fulfill breakfast with a low quality. Consumption patterns on teenagers today also like practicality and type of food is not monotonous. The aim of this study is to provide solutions to overcome breakfast for teenagers who like practicality with smoothies. The solution offered by a smoothie's business model is right to be used as a business opportunity in fulfilling the need for breakfast. This study uses a customer discovery approach with the Business Canvas model. The results of this study found that $100 \%$ of teenagers claimed to be interested in buying smoothies for breakfast with the value proposition of smoothies offered, which is a practical breakfast made from tropical fruits and vegetables mixed with milk and without artificial sweeteners. With positive responses from teenagers, the sale of smoothies can be done through collaboration with schools and colleges for the availability of smoothies for students and college students. The financial results of the smoothie's business show that this business is profitable.
\end{abstract}

Keywords: breakfast, business model canvas, customer discovery, smoothies

\begin{abstract}
Abstrak: Sebagian besar remaja di Indonesia mengabaikan sarapan sebagai aktivitas penting dan memenuhi sarapan dengan kualitas yang rendah. Pola konsumsi pada remaja saat ini juga menyukai kepraktisan dan jenis makanan yang tidak monoton. Tujuan penelitian ini adalah untuk memberikan solusi mengatasi sarapan pagi bagi remaja yang menyukai kepraktisan dengan smoothie. Solusi yang ditawarkan model bisnis smoothie ini tepat dijadikan sebagai peluang bisnis dalam memenuhi kebutuhan sarapan pagi. Penelitian ini menggunakan pendekatan penemuan pelanggan dengan model Business Canvas. Hasil penelitian ini menemukan bahwa 100\% remaja mengaku tertarik membeli smoothies untuk sarapan pagi dengan proposisi nilai smoothies yang ditawarkan, yaitu sarapan praktis berbahan buah-buahan dan sayuran tropis yang dicampur susu dan tanpa pemanis buatan. Dengan respon positif dari para remaja, penjualan smoothie dapat dilakukan melalui kerjasama dengan pihak sekolah maupun perguruan tinggi untuk ketersediaan smoothie bagi pelajar dan mahasiswa. Hasil finansial dari bisnis smoothie ini menunjukkan bahwa bisnis ini menguntungkan.
\end{abstract}

Kata kunci: sarapan, kanvas model bisnis, penemuan pelanggan, smoothie

\footnotetext{
${ }^{1}$ Corresponding author:

Email: novsa_fakhira@apps.ipb.ac.id
} 


\section{INTRODUCTION}

Anggraeni (2014) states many people ignore breakfast for various reasons. One reason is the lack of time to prepare breakfast due to the rush in the morning. The results of studies in Indonesia conducted in six major cities (Jakarta, Bandung, Semarang, Yogyakarta, Surabaya, Denpansar) show that there are $14-25 \%$ of teenagers not having breakfast. Some of the reasons teenagers never eat breakfast or rarely breakfast is because there is no available food to eat. This is because parents who work do not have time to make breakfast for their children. In addition, the food menu available at home is not interesting, the type of food provided is monotonous (boring), not get used to eat in the morning, lazy to prepare food, not have enough time (limited time) because they have to leave early in the morning (Khomsan, 2005).

The types of food consumed by Indonesians as breakfast are still low (Hardinsyah, 2012). The types of breakfast that are mostly consumed by teenagers in six big cities in Indonesia are rice and side dishes, fried rice, bread, and instant noodles. In addition to these foods there are other types of food that are widely consumed in certain cities. These foods are chicken porridge (Jakarta, Bandung and Semarang); Gudeg rice (Yogyakarta), rawon rice, soto rice, and pecel rice (Surabaya). Suyanto (2011) states that there is a significant relationship between breakfast and learning achievement in Malang. It is proved from the children who eat breakfast regularly have a good learning achievement of $65 \%$. Whereas children with irregular morning eating habits experience sufficient learning achievement of $35 \%$. The high frequency of skipping meals (especially breakfast), the high frequency of eating snacks, eating irregularly, and consuming animal based foods and fruits in low amounts will result in growth and poor learning achievement. Children who have breakfast habits will have better abilities than children who do not have breakfast habits (Skinner, 2000).

The consumption patterns of adolescents who like practicality and type of food are not monotonous, including at breakfast, encouraging companies in the food industry to create various alternative products for breakfast. Currently the breakfast menu can be found everywhere, such as oats, bread, cereals and milk which can be found everywhere. Breakfast products such as Energen, Koko Crunch, Milo, and Quaker Oats are popular breakfast menus in Indonesia. Following are the Top Brand Index data for breakfast product categories in Indonesia. breakfast products with the brand Energen being the most preferred beverage by the public with a percentage of $78,22 \%$. In the second place is occupied by Koko Krunch by 12,95\%, third is Milo cereal with a percentage of 3,12\% and in the last sequence there is Quaker Oat with a percentage of $1,41 \%$. Although practical breakfast products are available, teenagers still leave breakfast. The above conditions encourage other business opportunities to fulfill breakfast through smoothies. Smoothies are used as a solution to overcome breakfast for teenagers who like practicality strengthened by the beverage market which is a segment of the food industry that is quick to innovate and change compared to other industries. Innovations made are that thirst removal products develop into flavor enhancers, aroma, add vitamin content and add practicality to consuming by packaging products in packages that are adjusted to your needs. This study aims to develop a smoothie's business model that is appropriate for alternative breakfast for teens.

\section{METHODS}

The primary data in this study obtained from the results of in-depth interviews and online surveys to respondents. Secondary data were obtained from literature studies through various sources, such as books, papers, theses and journals. The population in this study were teenagers aged 12-21 years which included junior high, high school, and college students. Respondents were taken based on the non-probability sampling method with purposive sampling technique.

Qualitative data analysis is carried out during the process in the field together with data collection. Activities in data analysis include data reduction, data display, and conclusion drawing / verification. Data reduction is summarizing, choosing the main things, focusing on the things that are important, and looking for themes and patterns. Display data can be done in the form of brief descriptions, charts, relationships between categories, flowcharts and etc. Conclusion drawing or verification is drawing conclusions in accordance with the findings obtained during the study (Miles and Huberman, 1992).

This research uses customer discovery method with action research approach. Action research is an 
approach that focuses on the changes experienced from extracting information with a particular cycle, namely determining the problem, planning, taking action, and evaluating to get the right change (Saunders et al. 2009). The research began with problem testing, solution testing, market analysis, BMC, and business profits.

The test problem is done to understand the problems faced by customers. Data analysis at the problem testing stage begins with the transcription technique, which converts oral data into writing, then continues with the reduction technique. Reduction techniques include summarizing, sorting, and focusing to simplify data (Bungin, 2006). Data were analyzed with categorization techniques to classify respondents' responses to product solutions.

Testing the solution by presenting a value proposition in the form of products, determining the selling price, features, and other business components and MVP to customers. The initial step at this stage is the presentation of a solution in the form of MVP, which is a product/solution that is developed with the features expected by the respondent when testing a problem. MVP is used to be tested at the solution test stage. The next step is to compile a list of questions to test the product/solution on the respondent. Solution testing is conducted on respondents who are included in the criteria of potential consumers. Data collection at this stage was carried out by the method of giving questionnaires and interviews. The data obtained include consumer respondents' acceptance of the aspect of features, pricing that consumers can afford to pay, and the place of purchase of the product that the respondent is interested in. Market magnitude analysis is carried out to determine the amount of revenue that can be obtained by an industry. The market size consists of the Total Addressable Market (TAM), Serve Available Market (SAM), and Target Market (TM).

At the stage of preparing the business model consists of three components, there are verification of product/ market compatibility, verification of customers and how to reach, as well as verification of the revenue obtained. The preparation of the business model canvas (BMC) is done by designing the initial business model based on the hypothesis of market acceptance to be tested. According to Osterwalder and Pigneur (2012), a business model can illustrate the rationale for how organizations create, deliver, and capture value. Osterwalder divides the canvas into nine main components, then separated into the right component (creative side) and left (logical side). At the initial stage of preparing the business model canvas (BMC), the analysis is carried out using a categorization technique of the eleven BMC elements which are then extracted as input for the next stage.

The feasibility of a smoothie's business is done by calculating profits using the Revenue Cost Ratio (R/C) method. Revenue Cost Ratio $(\mathrm{R} / \mathrm{C})$ is a method for analyzing the financial benefits of a business, whether the business provides profits or not. $\mathrm{R} / \mathrm{C}$ is used to determine the ratio between total revenue (revenue) and total production costs (cost) (Soekartawi, 2006)

\section{RESULTS}

\section{Testing Problems}

Problems that often arise in respondents who do not like breakfast include: 1) respondents did not have time to eat breakfast due to time constraints and hassle if they have to provide breakfast chosen by $58 \%$ of respondents, 2) no one provides breakfast at home or the absence breakfast as much as $18 \%$ of respondents, 3 ) respondents are not ordinary breakfast felt by $16 \%$ of respondents, 4) as much as $6 \%$ of respondents feel sick stomach if having breakfast, 5) lack of appetite for breakfast as much as $2 \%$ of respondents.

The results showed that respondents' considerations at breakfast included: 1) practical breakfast to bring and eat or ease in providing breakfast as much as $27 \%$ of respondents, 2) benefits for the body from eating breakfast as much as $24 \%$ of respondents, 3 ) taste good breakfast was chosen by $19 \%$ of respondents, 4 ) ease of obtaining products was chosen by $18 \%$ of respondents, 5) affordable prices by $11 \%$ of respondents, 6 ) breakfast that did not make stomach ache as much as $1 \%$ of respondents.

Based on the results of the study, problems that often arise when consuming smoothies include: 1) impractical if you have to make your own smoothies felt by $36 \%$ of respondents, 2) the price of smoothies is quite expensive experienced by $27 \%$ of respondents, 3 ) difficulties in obtaining smoothies because not many who sell are chosen by $21 \%$ of respondents, 4 ) sense of smoothies that are not in accordance with what respondents want as many as $14 \%$ of respondents, 5) 
smoothies that if consumed make stomach pain felt by $1 \%$ of respondents, 6 ) Smoothies have a runny texture that is not liked by $1 \%$ of respondents. From these problems, there are solutions to overcome them looking for smoothies ready to drink and with more effective packaging to carry and drink, look for other smoothies at a more affordable price, look for smoothies through online channels, avoid smoothies that taste weird, avoid smoothies that make stomachace and look for other smoothies with a not too runny texture.

Packaging is a feature that is also very influential to make respondents interested in consuming smoothies. The results showed as many as $56 \%$ of respondents chose packaging that contained information about the benefits of beverage smoothies, and as many as $44 \%$ of respondents chose packaging with attractive designs. The results showed that the most preferred smoothies package by respondents was the bottle packaging chosen by $57 \%$ of respondents. This is because bottle packaging is easier to carry anywhere and anytime. Bottle packaging is also more effective compared to packaging in the bowl chosen by $25 \%$ respondents, zipper plastic by $10 \%$ respondents and cup packaging by $7 \%$ respondents.

\section{Testing Solution}

100\% respondents are interested in Trophy Smoothies products as breakfast because this product is an alternative breakfast made from tropical fruits and vegetables mixed with milk and without artificial sweeteners so it is good for the health of the body. This product is also practically used as breakfast because it uses bottled packaging so it can be consumed anywhere.

The solution test phase is carried out by giving a sample of the Trophy Smoothies (prototype) product to respondents. Researchers made Trophy products with 2 variants of flavors namely apple-cucumber smoothies and orange-carrot smoothies with $250 \mathrm{ml}$ bottle sizes. The composition of the two flavor variants is pure from fruits and vegetables and without artificial sweeteners. The flavor variants made are apple-cucumber smoothies mixed with water and milk, and orange-carrot smoothies mixed with water, milk, and honey.
These apple-cucumber and orange-carrot smoothies have very good benefits for the body. In apple and cucumber smoothies there is quercetin, which is one of two compounds that help reduce dead cells causing decreased brain performance (Experimental Biology and Medicine, 2006). Studies in the Journal of Alzheimer's Disease also suggest eating apples that are believed to be able to increase the production of essential neurotransmitter acetylcholine in the brain to improve memory.

Based on the results of the study, respondents of the Trophy Smoothies wanted a healthy breakfast with practical packaging. Practicality is defined as packaging having a small size so that the product is easy to carry and consume anytime and anywhere. Smoothies packaging consists of primary packaging made of plastic bottles (Figure 1). Each bottle of smoothies has a $250 \mathrm{ml}$ clear content. The price paid by respondents for one package of Trophy Smoothies is around Rp10,000-Rp20,000 per $250 \mathrm{ml}$ bottle. From the interviews it was found that 1 respondent chose the price of Rp12,000 smoothies, 1 other respondent chose the price of Rp12,500, as many as 2 respondents were able to pay smoothies worth Rp15,000, and 1 other respondent chose Rp17,000. In the product packaging there are also trademarks and advantages of each product, namely the apple and cucumber smoothies have the advantage of improving brain performance, keeping the body hydrated and detoxifying the body. The advantages of orange and carrot smoothies are to increase body immunity, keep skin fresh, smoothies can be used as diet drinks, and have high fiber.

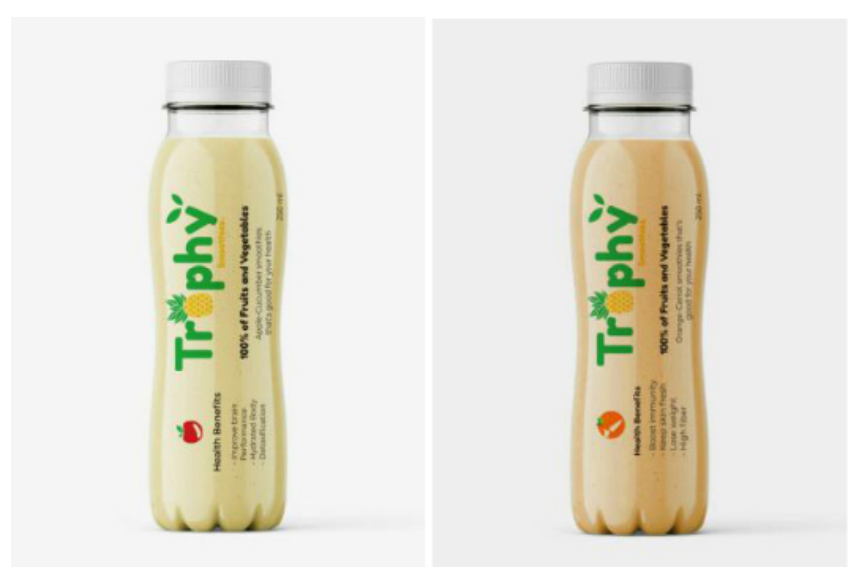

Figure 1. Trophy Smoothies packaging $250 \mathrm{ml}$ 
Total Available Market (TAM) is the overall market potential that has the opportunity to become a consumer of the products offered by business owners. The population of Bogor City is based on data from the 2017 Central Statistics Agency as many as 1,081,009 people. In the consumer segment, namely adolescents aged 12-21 years, the TAM of Trophy Smoothies beverage products in Bogor City is 282,896 inhabitants.

Served Available Market (SAM), which is how much the business owner can reach with the business model that has been designed. Respondents want to consume smoothies because of the benefits of fruits and vegetables in smoothies that are good for the body, taste that can be adjusted, attractive appearance, and practicality of the drink. Based on data acquisition, the market share that requires value from smoothies products is assumed to be $72.5 \%$ of the total TAM. The percentage is taken from the number of respondents who used to eat breakfast on the test problem. There fore the SAM is estimated at 205,100 inhabitants. However, this amount represents the market share for all producers of smoothies drinks in the city of Bogor. If the business model takes $30 \%$, then the number of SAMs is estimated at 61,530 people.

Target Market (TM) is part of the market share that actually becomes the user of the product being offered. TM is assumed to be $84,3 \%$ of the total SAM, as many as 51.870 people. The percentage is obtained from the problem test results, where respondents want breakfast with smoothies.

The smoothie's business model uses a business model canvas (BMC) which is based on the results of testing problems and solutions and determining the suitability of the business model for the business to be run. According to Blank and Dorf (2012), there are three things that are taken into consideration in verifying the business model canvas, namely the compatibility of the product with the customer, the customer segment with the channel, and the profit generated by the business model.

\section{Product Compatibility with The Market}

Suitability of the product with the market (product market fit) can be said to be good if it meets three components, namely the problems faced by consumers are important enough to be resolved, the product has features that can solve consumer problems, and there is a large enough number of markets to provide benefits to the business.

The target consumers are adolescents aged 12-21 years who want a practical breakfast and pay attention to the benefits of the product. Teenagers have a problem when breakfast is not having time for breakfast because of limited time and hassle if they have to provide breakfast. In addition, in the morning no one provides breakfast at home or there is no breakfast so teenagers choose not to have breakfast. Teenagers are not accustomed to having breakfast where it has become their habit to not eat breakfast. Another reason is teenagers feel sick to the stomach when having breakfast, and teenagers do not have an appetite for breakfast. Teenagers overcome these problems in various ways such as looking for breakfast that is easier to prepare, buying breakfast elsewhere/looking for breakfast that is easily obtained, and trying variants of the menu at breakfast.

At the test stage the problem of target consumers has problems when consuming smoothies that is not practical, the price of smoothies is quite expensive, the difficulty in obtaining smoothies because not many people sell these products, drinking smoothies can make the stomachache, and the texture is too runny. Consumers also have solutions to these problems, such as looking for ready-to-drink smoothies in bottles, looking for smoothies at a more affordable price, looking for smoothies through online sales channels, and avoiding buying smoothies with a watery texture. In the solution testing phase, consumers express an interest in the product being tested. Consumers assume that the product already has features that can address consumer problems, such as smoothies that are already in bottle packaging so that it makes it easier to consume in the morning and has good benefits for the body. Consumers suggest giving a price that is not too expensive so that Trophy products can be purchased by teenagers.

\section{Customer Segments and Channels}

Based on the results of test solutions, the right way to reach customers using online and offline media. Online sales channels with promotions on social media such as Instagram and Facebook, sales through online motorcycle taxi, marketplace and pre-orders via Whatsapp or Line. While offline sales channels 
by following the bazaar/events so that the product is better known by many people, selling at retail, canteen/ school cooperatives, as well as cooperation with schools or colleges. The collaboration is carried out by educating students about the importance of breakfast and subsidizing the Trophy Smoothies product as a breakfast for students and students.

The targeted customer segment has a significant opportunity to buy Trophy Smoothies products. The selling price of the product is Rp14,000 per bottle with a net weight of $250 \mathrm{ml}$. The cost of production is Rp10,415 and the mark-up is $34.42 \%$.

\section{Business Ability to Make Money}

Sources of operating income are obtained from the sale of Trophy Smoothies products to consumers through social media, bazaars, retail and marketplaces. The selling price of the product is set at Rp14,000 per bottle with a net weight of $250 \mathrm{ml}$. The price is obtained from the results of test solutions and benchmarks with Antowijaya Fruit. The cost of producing Trophy Smoothies is Rp10,415 and the mark-up is Rp3,585 or $34.42 \%$.

In the first year, Trophy Smoothies plans to produce 24,000 packages per year, equivalent to 100 packages per day with 240 working hours a year. Estimated sales of $100 \%$ of the total production of 24,000 packages per year, thus earning a net income of $\mathrm{Rp} 86,050,400$. This venture capital of Rp100,000,000 with 100\% using their own capital.

\section{Analysis of Financial Benefits}

Making a Trophy Smoothies business requires an analysis of business profits from the financial aspect. This is done to find out whether the business to be run profit or not. The financial planning used in the calculation of the business profit analysis is cash flow analysis which consists of Revenue Cost Ratio (R/C). Business investment costs are costs required to procure production equipment including blenders, freezers, cash registers, motorcycles, spoons, and others that require funds of Rp35,528,000. The business capital needed is Rp100,000,000 with $100 \%$ using their own capital.

Production costs are the total costs incurred by a company in the production process. From the calculation, the production cost in the first year is Rp185,208,000 which produces 24,000 bottles of Trophy Smoothies per year or equivalent to 100 bottles per day. Trophy Business produces 100 bottles per day obtained from the benchmark and

constitutes $0.2 \%$ of the target market. The number and production cost planning in this business will increase by $5 \%$ every year. Operational costs consist of promotional costs and distribution costs that increase every year in accordance with the amount of production produced.

In the calculation results it is found that the operational costs of Rp6,156,000 Fixed costs are costs that do not affect the amount of production and the amount of costs will be the same every year. In this study classified as fixed costs are employee salaries, rental of production sites, depreciation of equipment and machinery, and stationery. The total fixed cost (TC) for the Smoohies Trophy is Rp58,585,600. The Cost of Production (HPP) of one bottle of Trophy Smoothies with a net weight of $250 \mathrm{ml}$ is Rp10,415 with a mark up of $34.42 \%$, the company gets a profit of Rp3,585 per bottle with a selling price of Rp14,000.

Revenue is the total of the production or service sold multiplied by the price. From the calculation, the total revenue (TR) obtained from the Trophy Smoothies business was Rp336,000,000. While revenue is the result of revenue which is reduced by production costs. Based on the calculation, the income (I) of this business is $\mathrm{Rp} 86,050,400$.

Planning the financial profit analysis of the Trophy Smoothies business shows that this business is profitable. The following summarizes the results of a business profit analysis from the financial aspect which is presented in Table 1.

Table 1. Analysis of the Benefits of the Trophy Smoothies Business

\begin{tabular}{ccc}
\hline $\begin{array}{c}\text { Measuring } \\
\text { Instrument }\end{array}$ & $\begin{array}{c}\text { Measurement } \\
\text { Results }\end{array}$ & Profit/Loss \\
\hline $\mathrm{R} / \mathrm{C}$ & 1,3 & Profit \\
\hline
\end{tabular}

Revenue Cost Ratio ( $\mathrm{R} / \mathrm{C}$ ) is the ratio value between total revenue and total cost. The total revenue (TR) received by the Trophy Smoothies business is Rp336,000,000 and the total cost (TC) incurred is Rp249,949,600. Based on the calculation of R/C, it can be concluded that the Trophy Smoothies business 
is declared profitable to run. This can be seen from the comparison of total revenue and total costs greater than one, which has a number 1.3> 1. In other words, an $\mathrm{R} / \mathrm{C}$ value of 1.3 means that for every Rp100 of costs incurred, the Trophy Smoothies business earns an income of Rp130. Analysis of business financial benefits has a calculation that refers to the cash flow results of the Trophy Smoothies business.

\section{Managerial Implications}

With positive responses from teenagers and positive financial results of the smoothie's business, the sale of smoothies can be done through collaboration with schools and colleges for the availability of smoothies for students and college students. The easiest way to do the collaboration is being a sponsor for schools or colleges' events. The company can give them free product to be shared with the event's participants to make the product well-known and placement of the product in the market needs to be reachable. So, when they want to start purchasing the product, they can find it easily.

\section{CONCLUSIONS AND RECOMMENDATIONS}

\section{Conclusions}

The smoothie's business model for breakfast targets young people aged 12-21 who want a practical breakfast. The initial value proposition offered is practical breakfast because consumers want to consume smoothies easily anywhere and anytime. In addition, smoothie's products made from fruits, vegetables, milk, and without artificial sweeteners, as well as packaging in the form of bottles with attractive designs can make it easier for customers to bring products anywhere.

The calculation results of business financial analysis show that the Revenue Cost Ratio (R/C) of 1.3 is more than 1 . In other words, an $\mathrm{R} / \mathrm{C}$ value of 1.3 has a meaning for every Rp100 costs incurred, then the Trophy Smoothies business gets income of Rp130. This shows that the Trophy Smoothies business is profitable to run.

\section{Recommendations}

Based on the result, $100 \%$ teenagers responded the Trophy Smoothies in positive way. It means, as a producer, Trophy Smoothies' Company should optimize this opportunity to market the product widely to the canteen's school and university, give compensation to the canteen that sales the product, and being a sponsor in events held by school or universities. Trophy Smoothies also could place their product within teenager's reach, such as in canteen, minimarket, and marketplace.

\section{REFERENCES}

Anggraeni A. 2014. Hubungan Pola Konsumsi Makanan Jajanan Dengan Status Gizi dan Kadar Kolesterol Pada Anak Sekolah Dasar Negeri IKIP 1 Makasar [skripsi]. Makassar: Universitas Islam Negeri Alauddin Makasar.

Blank S, Dorf B. 2012. The Startup Owner's Manual: The Step-by-Step Guide for Building a Great Company. California : K\&S Ranch, Inc. Publisher.

Miles MB, Huberman AM. 1992. Qualitative Data Analysis: A Resource Book about New Methods. Jakarta: UI Press.

Hardinsyah et al. 2012. Kebiasaan Sarapan Anak Indonesia berdasarkan Data Riskesdas 2010. Jurnal Gizi dan Pangan

Khomsan A. 2005. Pangan dan Gizi untukKesehatan. Jakarta: PT. Raja. Grafindo Persada.

Skinner. 2000. Prinsip Dasar Ilmu Gizi. Jakarta: PT Gramedia Pustaka Utama.

Soekartawi, 2006. Analisis Revenue Cost. Jakarta:PT. Raja Grafindo Persada.

Suyanto WH. 2011. Kebiasaan Sarapan di Sekolah dan Status Gizi dengan Prestasi Belajar [skripsi]. Malang: Fakultas Kedokteran Universitas Brawijaya. 